\title{
Effects of essential oils on rumen fermentation, milk production, and feeding behavior in lactating dairy cows
}

\author{
L. R. Tager and K. M. Krause ${ }^{1}$ \\ Division of Animal and Nutritional Science, West Virginia University, Morgantown 26506
}

\begin{abstract}
Seven ruminally cannulated lactating Holstein dairy cows were used in an incomplete Latin rectangle design to assess the effects of 2 commercial essential oil (EO) products on rumen fermentation, milk production, and feeding behavior. Cows were fed a total mixed ration with a $42: 58$ forage:concentrate ratio (DM basis). Treatments included addition of $0.5 \mathrm{~g} / \mathrm{d}$ of CE Lo $(85$ $\mathrm{mg}$ of cinnamaldehyde and $140 \mathrm{mg}$ of eugenol), $10 \mathrm{~g} / \mathrm{d}$ of CE Hi (1,700 mg of cinnamaldehyde and 2,800 mg of eugenol), $0.25 \mathrm{~g} / \mathrm{d}$ of CAP (50 mg of capsicum), or no oil $(\mathrm{CON})$. Cows were fed ad libitum twice daily for $21 \mathrm{~d}$ per period. Dry matter intake, number of meals/d, $\mathrm{h}$ eating/d, mean meal length, rumination events/d, h ruminating/d, and mean rumination length were not affected by EO. However, length of the first meal after feeding decreased with addition of $\mathrm{CE} \mathrm{Hi} \mathrm{(47.2} \mathrm{min)}$ and CAP (49.4 min) compared with CON (65.4 min). Total volatile fatty acids, individual volatile fatty acids, acetate:propionate ratio, and ammonia concentration were not affected by EO. Mean rumen $\mathrm{pH}$ as well as bouts, total h, mean bout length, total area, and mean bout area under $\mathrm{pH} 5.6$ did not differ among treatments. Total tract digestibility of organic matter, dry matter, neutral detergent fiber, acid detergent fiber, crude protein, and starch were not affected by EO. Milk yield and composition did not change with EO. In situ dry matter disappearance of ground soybean hulls was not affected by EO. However, organic matter disappearance of soybean hulls with $\mathrm{CE}$ Hi tended to decrease compared with CON. Compared with CON, neutral detergent fiber disappearance (41.5 vs. $37.6 \%$ ) and acid detergent fiber disappearance ( 44.5 vs. $38.8 \%$ ) decreased with addition of CE Hi. The CE Lo had no effect on rumen fermentation, milk production, or feeding behavior but CAP shortened the length of the first meal without changing rumen fermentation or production, making it a possible additive for altering feeding behavior. The CE Hi negatively affected rumen
\end{abstract}

Received June 4, 2010.

Accepted January 7, 2011.

${ }^{1}$ Corresponding author: Marie.Krause@mail.wvu.edu fermentation and shortened the length of the first meal, suggesting that a dose of $10 \mathrm{~g} / \mathrm{d}$ is not beneficial to lactating dairy cows.

Key words: essential oil, dairy cow, rumen fermentation, feeding behavior

\section{INTRODUCTION}

Many essential oils (EO) have been shown to affect rumen fermentation (Wallace, 2005) and they are currently being studied as rumen modifiers in ruminants. Several of the studies on EO have been done using in vitro methods such as batch culture and continuous culture (Castillejos et al., 2005; Fraser et al., 2007; Tager and Krause, 2010). Data from these studies are often inconclusive and lead to conflicting results due to variation of dosages, chemical structure of EO compounds, diets, blends, and EO providers (Calsamiglia et al., 2007). Often, in vitro studies require a very high dosage (>100 mg/L per day) to elicit an observable response, which would be equivalent to feeding $>10 \mathrm{~g}$ of $\mathrm{EO} /$ cow per day (assuming a 100-L rumen volume) in vivo. For most EO, this is $>5$ times the manufacturer's recommended feeding dosage. However, to the best of our knowledge, no research using such high dosages has been done in vivo, making it difficult to extrapolate in vitro research to real-life applications.

Cinnamaldehyde (CIN), eugenol (EUG), and capsicum (CAP) are known to have antimicrobial properties, and have been suggested to act as rumen modifiers (Calsamiglia et al., 2007). However, in vitro, CIN, EUG, and CAP often have little effect on microbial fermentation except at very high dosages $(>300 \mathrm{mg} / \mathrm{L}$ of rumen fluid; Busquet et al., 2006). In vivo, however, a high-concentrate diet fed to beef cattle (10:90 forage:concentrate ratio), supplemented with CIN, EUG, or CAP provided some positive effects on rumen fermentation at lower EO dosages $(\leq 1.0 \mathrm{~g} /$ cow per day), leading to increased feed digestibility (Cardozo et al., 2006). Further, supplementing CAP to beef cattle has been shown to stimulate DMI without decreasing rumen pH (Fandiño et al., 2008; Rodriguez-Prado et al., 2008), however, no such work has been done in the lactating dairy cow. 
Although CIN, EUG, and CAP have been studied extensively in vitro, much less is known about their effects in the lactating dairy cow. Moreover, most of the in vivo work on these $\mathrm{EO}$ has been done in beef cattle and little is known about how these EO affect feeding behavior, rumen fermentation, and milk production in lactating dairy cows. Further, whereas CIN and EUG have been shown to alter rumen fermentation in vitro at high dosages, their effects at high dosages in vivo are unclear. Consequently, the objective of this study was to assess the effects of a manufacturer's recommended dosage of CAP as well as a blend of CIN and EUG at the manufacturer's recommended dosage and a high dosage closer to levels used in vitro, on rumen fermentation, milk production, and feeding behavior in lactating dairy cows.

\section{MATERIALS AND METHODS}

\section{Experimental Design, Animals, and Diet}

Eight ruminally cannulated Holstein cows (4 primiparous and 4 multiparous) were randomly assigned to 4 treatments within a Latin rectangle design. Average BW was $566 \pm 55 \mathrm{~kg}$ at the beginning of the experiment and $634 \pm 61 \mathrm{~kg}$ at the end of the experiment. Cows averaged $43 \pm 29$ DIM at the beginning of the study. The experiment consisted of four 21-d periods with 14 $\mathrm{d}$ of adaptation and $7 \mathrm{~d}$ of sampling. The experiment was approved by the West Virginia University Animal Care and Use Committee and was conducted at the West Virginia University Research Farm.

Diets were fed as TMR with forage-to-concentrate ratio of 42:58 (DM basis) formulated to support $45 \mathrm{~kg} / \mathrm{d}$ of milk production in a $623-\mathrm{kg}$ cow with a predicted DMI of $24.9 \mathrm{~kg} / \mathrm{d}$ (NRC, 2001). Dietary ingredients and nutrient composition are shown in Table 1. Cows were fed ad libitum twice daily at 0800 and $1900 \mathrm{~h}$ in equal portions using the Calan gate feeding system (American Calan Inc., Northwood, NH). Water was available ad libitum. The cows were milked twice daily at 0830 and $1930 \mathrm{~h}$.

\section{Preliminary Study}

One major objective of this study was to examine the effects of feeding oils at a level closer to high in vitro dosages used in a prior experiment $(500 \mathrm{mg} / \mathrm{L}$ per day, $\sim 50 \mathrm{~g} /$ cow per day; Tager and Krause, 2010). However, feeding oils at such high levels may affect intake due to palatability problems. Therefore, to determine the highest dosage of XT 6965 (85 mg of CIN and 140 mg of EUG; Pancosma S.A., Bellegarde-sur-Valserine, France) that could be fed to cows before affecting intake,
Table 1. Diet ingredient, chemical composition, and particle size distribution of the TMR

\begin{tabular}{|c|c|}
\hline & $\begin{array}{c}\text { Percentage of } \\
\text { total DM }\end{array}$ \\
\hline \multicolumn{2}{|l|}{ Item } \\
\hline Corn silage $^{1}$ & 34.4 \\
\hline Ground corn grain & 32.0 \\
\hline Soybean hulls & 11.0 \\
\hline Chopped alfalfa hay ${ }^{2}$ & 7.3 \\
\hline Hydrolyzed feather meal & 2.9 \\
\hline Calcium diphosphate & 0.5 \\
\hline Salt & 0.5 \\
\hline Limestone & 0.3 \\
\hline Urea & 0.3 \\
\hline Vitamin premix & 0.3 \\
\hline Magnesium oxide & 0.1 \\
\hline \multicolumn{2}{|l|}{ Nutrients, DM basis } \\
\hline DM, as fed basis & 64.0 \\
\hline $\mathrm{OM}$ & 94.8 \\
\hline $\mathrm{CP}$ & 16.3 \\
\hline $\mathrm{NDF}$ & 28.6 \\
\hline $\mathrm{ADF}$ & 19.1 \\
\hline Starch & 29.6 \\
\hline NSC & 32.2 \\
\hline Ether extract & 2.3 \\
\hline \multicolumn{2}{|c|}{ Particle size distribution, as fed basis ${ }^{3}$} \\
\hline$>19.0 \mathrm{~mm}$ & 5.9 \\
\hline $19.0-8.0 \mathrm{~mm}$ & 29.1 \\
\hline $8.0-1.18 \mathrm{~mm}$ & 49.8 \\
\hline$<1.18 \mathrm{~mm}$ & 15.2 \\
\hline $\mathrm{X}_{\mathrm{gm}}{ }^{4}$ & 4.8 \\
\hline
\end{tabular}

${ }^{1}$ Nutrient analysis (DM basis): $39.7 \%$ DM (as fed); $42.9 \%$ NDF; $22.4 \%$ ADF; $46.1 \%$ starch; $2.8 \%$ ash; $2.6 \%$ ether extract; $5.0 \%>18$-mm particle size; $64.8 \%$ 9-18-mm particle size; $28.4 \%$ 1.18-9-mm particle size; $1.8 \%<1.18-\mathrm{mm}$ particle size.

${ }^{2}$ Nutrient analysis (DM basis): $84.8 \%$ DM (as fed); $42.5 \%$ NDF; $31.7 \%$ ADF; $3.1 \%$ starch; $9.7 \%$ ash; $1.3 \%$ ether extract; $4.1 \%>18-\mathrm{mm}$ particle size; $28.1 \%$ 9-18-mm particle size; $44.3 \%$ 1.18-9-mm particle size; $23.5 \%<1.18$-mm particle size.

${ }^{3}$ As determined by the Penn State Particle Separator.

${ }^{4}$ Calculated geometric mean length (ASAE, 2001).

a preliminary study was conducted using the GrowSafe System (GrowSafe Systems Ltd., Airdrie, AB, Canada). Fourteen cows were assigned to a bay with 5 Growsafe bins. Cows were fed ad libitum a TMR (68.2\% DM with $96.1 \% \mathrm{OM}, 14.8 \% \mathrm{CP}, 34.2 \% \mathrm{NDF}, 28.6 \% \mathrm{ADF}$, and $16.3 \%$ starch on a DM basis), with increasing dosages of XT 6965 randomly assigned to each bin (2 bins with $0.5 \mathrm{~g} /$ cow per day, 2 bins with $1.0 \mathrm{~g} /$ cow per day, and 1 bin with $2.0 \mathrm{~g} /$ cow per day). Dosages were randomly assigned to a new bin each day so cows would not learn where a specific dosage was fed. Eating behavior was observed for $5 \mathrm{~d}$, and when the highest dosage did not cause decreased intake, the study was continued again for $5 \mathrm{~d}$ with increased dosages (2 bins $2.0 \mathrm{~g} / \mathrm{cow}$ per day, 2 bins $4.0 \mathrm{~g} /$ cow per day, 1 bin $6.0 \mathrm{~g} /$ cow per day). This procedure continued ( $5 \mathrm{~d}$ with $4.0,6.0$, and $8.0 \mathrm{~g} / \mathrm{cow}$ per day and $5 \mathrm{~d}$ with 8.0, 10.0, and $12.0 \mathrm{~g} /$ cow per day) until feed intake was decreased at $12.0 \mathrm{~g} /$ cow per day. Therefore, the level of $10.0 \mathrm{~g} /$ cow per day 
was chosen as the high dosage for the current study, as this was the greatest level at which feed intake was unaffected.

\section{Experimental Treatments}

Based on manufacturer-recommended dosages and the preliminary study, experimental treatments included the addition of $0.5 \mathrm{~g}$ of XT $6965 /$ cow per day (CE Lo; recommended dosage; $85 \mathrm{mg}$ of CIN and 140 mg of EUG), $10 \mathrm{~g}$ of XT 6965/cow per day (CE Hi; high dosage; 1,700 $\mathrm{mg}$ of CIN and 2,800 $\mathrm{mg}$ of EUG), $0.25 \mathrm{~g}$ of XT $6933 /$ cow per day (CAP; recommended dosage; Pancosma S.A.), and no oil (CON). The CAP treatment was only applied at the recommended dosage to assess the effects of CAP mainly on feeding behavior, as prior in vitro research observed no effects of CAP on rumen fermentation at high dosages $(500 \mathrm{mg} / \mathrm{L}$; Tager and Krause, 2010).

\section{Sample Collection}

Forage, concentrate, and TMR samples were collected twice per period. Intake and orts were recorded and a subsample of orts was collected at each feeding during each sampling period. Samples for particle size separation were separated using the 3 -screen Penn State Particle Separator (Kononoff et al., 2003). Milk samples were collected and milk yields were recorded at each milking for the last $4 \mathrm{~d}$ of each experimental period.

To determine total tract digestibility of feed nutrients, lanthanum (La) in solution was used as a marker to estimate fecal output (Hartnell and Satter, 1979) and was ruminally dosed after each milking throughout the entire study to provide $0.8 \mathrm{~g} \mathrm{La} / \mathrm{cow}$ per day. Ten fecal samples/cow per period were collected at differing times throughout the $7 \mathrm{~d}$ of sampling to represent a 24 -h period and account for diurnal variation. Fecal samples were immediately frozen, then later dried at $60^{\circ} \mathrm{C}$, pooled by period for each cow and ground through a 1-mm screen using a Wiley Mill (Arthur H. Thomas Co., Philadelphia, PA).

Based on depressed nutrient digestibility with EO in a prior continuous culture study (Tager and Krause, 2010), OM, DM, NDF, and ADF disappearance was assessed using in situ 24-h ruminal degradation of ground soybean hulls (4-mm screen). Soybean hulls were selected for this analysis due to their high fiber content. In situ bags made of Dacron polyester cloth with a pore size of $52 \pm 5 \mu \mathrm{m}$ and $5 \times 10 \mathrm{~cm}$ in size were filled with $5 \mathrm{~g}$ of ground soybean hulls, weighed in quadruplet, placed in larger mesh bags, soaked in warm water for
$10 \mathrm{~min}$ and ruminally incubated for 0 and $24 \mathrm{~h}$ during d 6 of each sampling period. After removal from the rumen, bags were washed under cold, running tap water and then frozen for later analysis. Upon thawing, Dacron bags were rinsed in cold water until the water ran clear to ensure all residues were removed. Time 0 $\mathrm{h}$ bags were not placed in the rumen, but were subject to the same washing, freezing, and rinsing procedure. Bags were then dried at $60^{\circ} \mathrm{C}$ for $48 \mathrm{~h}$.

Rumen fluid was sampled (in relation to morning feeding) at times $0,1,2,4,6$, and $8 \mathrm{~h}$ during the first day of sampling for determination of VFA and ammonia concentrations. Rumen fluid was obtained by grab samples of the digesta from the anterior, medial, and posterior ventral locations of the rumen and then strained through 4 layers of cheesecloth. Three 10$\mathrm{mL}$ samples were taken and acidified with $0.5 \mathrm{~mL}$ of $\mathrm{H}_{2} \mathrm{SO}_{4}$ and frozen for later VFA analysis. Two $10-\mathrm{mL}$ samples were also acidified with $0.2 \mathrm{~mL}$ of $\mathrm{H}_{2} \mathrm{SO}_{4}$ and frozen for later determination of ammonia concentrations.

Continuous $\mathrm{pH}$ data were collected using a submersible Lethbridge Research Centre $\mathrm{pH}$ measuring system (LRCpH, Dascor, Escondido, CA). The LRCpH was inserted, with two 1-kg weights attached, into the ventral sac of the rumen for $96 \mathrm{~h}$. Before insertion into the rumen, $\mathrm{pH}$ readings were recorded in standard buffers of $\mathrm{pH} 4$ and 7 , and units were set to record $\mathrm{pH}$ every $30 \mathrm{~s}$. Data transfer from the logger to a computer were conducted every $24 \mathrm{~h}$ and occurred after the morning milking. During this time the logger was removed, logging was disabled, the data were downloaded and then the logger was returned to the respective cow. Standardizations of the $\mathrm{pH}$ electrodes were conducted after 48 and $96 \mathrm{~h}$; readings in standard buffer solutions of $\mathrm{pH}$ 4 and 7 were recorded and the data were downloaded. The shift in millivolt readings from the electrodes between the start and end standardizations were assumed to be linear and were used to convert millivolt readings to $\mathrm{pH}$ units (Penner et al., 2006).

Eating and ruminating behaviors were monitored visually for a 24-h period on the fourth day of each sampling period. Eating and ruminating activities were noted every $5 \mathrm{~min}$, and each activity was assumed to persist for the entire 5-min interval. A meal was defined as at least one observation of eating activity occurring after at least 20 min without eating activity. This is based on the definition of eating used by Wangsness et al. (1976) who defined a meal as at least 1 min of eating activity after at least 20 min without eating activity. A period of rumination was defined as at least $5 \mathrm{~min}$ of rumination occurring after at least 5 min without ruminating activity. 


\section{Laboratory Analyses}

Analytical DM of feed and fecal samples was determined by oven drying at $100^{\circ} \mathrm{C}$ for $24 \mathrm{~h}$ (AOAC, 1995; 967.03). Ether extraction of the feed was performed according to AOAC $(1995 ; 920.39)$. The ash content of feed and fecal samples was determined by combustion at $550^{\circ} \mathrm{C}$ overnight, and $\mathrm{OM}$ content was calculated as 100 minus the percentage of ash (AOAC, 1995; 942.05). Determination of the NDF and ADF content in feed and fecal samples was done using the Ankom 200 Fiber Analyzer (Ankom Technology Corp., Macedon, NY). The total $\mathrm{N}$ content in feed and ammonia concentration of rumen samples were analyzed according to AOAC (1995; 976.05) using an automated Tecator digestion system (Tecator, Inc., Herndon, VA). Analysis of VFA concentrations from rumen samples were performed using a gas chromatograph. The gas chromatograph was a Varian model 3300 with an FID detector (Varian, Inc., Palo Alto, CA). The column was a $2-\mathrm{m} \times 2-\mathrm{mm}$ glass column packed with $10 \% \mathrm{SP}-1200 / 1 \% \mathrm{H}_{3} \mathrm{HPO}_{4}$ on 80/100 Chromosorb WAW (Supelco, Inc., Bellefonte, PA). The concentrations of sugars in feed and fecal samples were determined by the extraction procedure adapted from Deriaz (1961). Reducing sugars were determined with a spectrophotometer and potassium ferricyanide. Starch content of feed and fecal samples was determined by the procedure of Smith (1969). Lanthanum concentrations were determined by dry ashing ground fecal samples at $500^{\circ} \mathrm{C}$ for $16 \mathrm{~h}$. The ashed samples were then dissolved in $70 \%$ nitric acid, diluted to 1:50 in distilled $\mathrm{H}_{2} \mathrm{O}$ and filtered twice through 42$\mu \mathrm{m}$ filter paper. Lanthanum concentrations were then determined by inductively coupled plasma spectroscopy (ICP). Fecal output was calculated based on La concentration in feces. Milk samples were sent to Dairy One (Ithaca, New York) for determination of lactose, protein, and milk fat.

\section{Statistical Analyses}

Data was analyzed using the mixed model procedure of SAS (2001; Version 9.1, SAS Institute, Cary, NC). The data from 1 primiparous cow was discarded due to health issues unrelated to dietary treatments for the entirety of the study. Therefore, results are analyzed as an incomplete Latin rectangle. Data that were not collected as repeated measures (total tract digestibility, in situ disappearance, feeding behavior, and milk production) were analyzed using a model including treatment as a fixed effect and period and cow as random effects. Ruminal variables collected as repeated measures ( $\mathrm{pH}$, ammonia, VFA concentrations and percentages, and acetate: propionate ratio) were analyzed using a model that included treatment and hours postfeeding as fixed effects along with their 2-way interaction. Period, cow, and cow by period were included as random effects in the model. Based on model fitting statistics a compound symmetry covariance structure was used for these analyses. Statistical analysis was conducted using a Kenward-Roger adjustment and reported as least squares means. Separation of means was performed on data with significant treatment differences and tendency for treatment differences, and a Tukey adjustment was used to make treatment comparisons. Differences were considered significant at $P \leq 0.05$ and considered a trend at $0.05<P \leq 0.10$

\section{RESULTS AND DISCUSSION}

\section{Feeding and Rumination Behavior}

Dry matter intake was not affected by EO (Table 2). It is important to note that the majority of in vivo literature addresses the use of EO either separately or in blends with more than 3 EO not present in this study. Therefore, caution should be taken in making specific conclusions between the current study and prior literature. Nonetheless, the lack of EO effect on DMI agrees with other research in dairy cattle consuming similar diets (0.75 to $2.0 \mathrm{~g}$ of $\mathrm{EO} / \mathrm{d}$; Benchaar et al., 2006, $2007,2008)$. Conversely, in beef heifers fed a 10:90 forage:concentrate ratio diet, CAP $(0.5 \mathrm{~g} / \mathrm{cow}$ per day $)$ increased DMI by $12.6 \%$ (6.57 to $7.42 \mathrm{~kg} / \mathrm{d}$; Fandiño et al., 2008). This difference in DMI between studies may be due to the difference in diet as well as the higher concentration of CAP consumed by beef cattle compared with that consumed in the current study. Dairy cattle have markedly higher DMI ( $>20.0 \mathrm{~kg}$ of DMI/d) compared with beef cattle $(<10.0 \mathrm{~kg}$ of DMI/d). Consequently, the concentration of EO consumed in the study by Fandiño et al. (2008) was approximately 71.8 $\mathrm{mg}$ of $\mathrm{CAP} / \mathrm{kg}$ of DM consumed, whereas the current study only provided a concentration of approximately $11.0 \mathrm{mg}$ of $\mathrm{CAP} / \mathrm{kg}$ of $\mathrm{DM}$ consumed. Therefore, a higher dosage of CAP may be necessary in dairy cattle to cause changes in DMI.

Essential oils had no effect on meal events/d, h of eating/d, mean meal length, rumination events/d, h of rumination/d, or mean rumination length (Table 2). Using the GrowSafe monitoring system (GrowSafe Systems Ltd.), Rodriguez-Prado et al. (2008) observed an increase in total h of eating/d (2.64 vs. $1.92 \mathrm{~h}$ ) as well as a more stable eating pattern (shorter, more frequent meals) in beef heifers fed a 10:90 forage-to-concentrate ratio diet supplemented with $0.5 \mathrm{~g}$ of $\mathrm{CAP} / \mathrm{d}$. Although overall intake was unaffected in the current study, the length of the first meal after feeding was shortened by 
Table 2. Feeding and rumination behavior of lactating Holstein dairy cows fed a 42:58 forage-to-concentrate ratio diet supplemented with essential oils

\begin{tabular}{|c|c|c|c|c|c|c|}
\hline \multirow[b]{2}{*}{ Item } & \multicolumn{4}{|c|}{ Treatment $^{1}$} & \multirow[b]{2}{*}{ SEM } & \multirow[b]{2}{*}{$P$-value } \\
\hline & $\mathrm{CON}$ & CE Lo & CE Hi & CAP & & \\
\hline DMI, $\mathrm{kg} / \mathrm{d}$ & 23.9 & 23.3 & 23.2 & 22.9 & 0.9 & 0.56 \\
\hline Meal events, $\mathrm{n} / \mathrm{d}$ & 7.3 & 7.0 & 7.6 & 7.7 & 0.6 & 0.65 \\
\hline Eating, $\mathrm{h} / \mathrm{d}$ & 4.2 & 3.5 & 4.1 & 4.0 & 0.4 & 0.53 \\
\hline Mean meal length. min & 35.3 & 35.6 & 34.0 & 30.7 & 2.8 & 0.20 \\
\hline Length of first meal, min & $65.4^{\mathrm{a}}$ & $58.7^{\mathrm{ab}}$ & $47.2^{\mathrm{b}}$ & $49.4^{\mathrm{b}}$ & 7.6 & 0.01 \\
\hline Rumination events, n/d & 10.2 & 10.3 & 10.0 & 10.5 & 0.6 & 0.57 \\
\hline Rumination, $\mathrm{h} / \mathrm{d}$ & 6.7 & 5.6 & 5.9 & 6.5 & 0.6 & 0.46 \\
\hline Mean rumination length, min & 39.3 & 39.2 & 35.7 & 37.0 & 2.5 & 0.52 \\
\hline
\end{tabular}

CE Hi and CAP (47.2 min and 49.4 min, respectively, vs. 65.4 min for CON; Table 2), suggesting that CE $\mathrm{Hi}$ and CAP may cause a change in the palatability of feed and alter feeding behavior. Shortening the length of the first meal, which is often the largest meal, may be beneficial in preventing acidosis, as it may help control the sharp decrease in rumen $\mathrm{pH}$ after feeding (French and Kennelly, 1990). Indeed, Rodriguez-Prado et al. (2008) observed a similar stabilization of feeding behavior in the beef heifers supplemented with 0.5 $\mathrm{g}$ of $\mathrm{CAP} / \mathrm{d}$. Therefore, whereas CE Hi may not be economically nor biologically appropriate as a feed additive, further behavioral research with CAP may help to better understand how it affects feeding behavior in the lactating dairy cow.

Although DMI, time spent eating/d, and time spent ruminating/d were comparable to other eating behavior studies, cows on all treatments ate fewer meals/d (7.0 to 7.7 meals/d vs. 8.2 to 11.6 meals/d) than usually observed in midlactation dairy cattle (Krause and Combs, 2003; Yang and Beauchemin, 2007). Consequently, the average meal length was longer in the current study (33.9 $\mathrm{min} / \mathrm{meal}$ ) than normally observed in dairy cattle $(\sim 26.5 \mathrm{~min} / \mathrm{meal}$; Krause and Combs, 2003; Yang and Beauchemin, 2007). This may have been caused by the increased amount of time spent sorting, as was evidenced by a higher NDF content in the orts (36.3\% NDF) than in the TMR $(28.6 \%$ NDF). Typically, dairy rations contain 40 to $60 \%$ DM (Eastridge, 2006), whereas the ration used in the current study contained 64.0\% DM. Rations with a high DM content and containing dry forages, such as the one fed in this study, often lead to increased sorting behavior (DeVries et al., 2007). Further, the larger, less frequent meals may be associated with the low rumen $\mathrm{pH}$ observed in cows for all treatments, as will be discussed in more detail later.

\section{Ammonia and VFA Concentration}

No effect of treatment or interaction between treatment and hours postfeeding on ammonia concentration was observed (Table 3). Ammonia concentrations behaved typically by increasing immediately after feeding, and beginning to decrease around 4 or $6 \mathrm{~h}$ postfeeding in most cows, as was evidenced by the effect of hours postfeeding $(P<0.01$; data not shown). Essential oils are not often reported to affect ammonia concentration in vivo with diets similar to the current study (Newbold et al., 2004; Benchaar et al., 2006, 2007, 2008; Fandiño et al., 2008). Again, it is important to point out that most prior literature examined EO separately or in blends with more than 3 compounds not present in this study, making it difficult to make specific comparisons between the current study and previous ones. Still, one study by Cardozo et al. (2006), observed no change in ammonia with CAP $(1 \mathrm{~g} / \mathrm{d})$ but did find a decrease with 2 combinations of CIN and EUG $(0.18 \mathrm{~g} / \mathrm{d}$ CIN $+0.09 \mathrm{~g} / \mathrm{d}$ EUG or $0.6 \mathrm{~g} / \mathrm{d}$ CIN $+0.3 \mathrm{~g} / \mathrm{d}$ EUG) in beef heifers fed a 10:90 forage:concentrate ratio diet. However, the diets between these studies were very different, and comparison between them should be made cautiously.

Essential oils did not affect total or individual concentrations of VFA, nor was there an interaction between diet and hours postfeeding (Table 3). Similar to ammonia, concentrations of total VFA, acetate, propionate, butyrate, and valerate increased immediately after feeding and did not decrease until 4 and $6 \mathrm{~h}$ postfeeding $(P<0.01$; data not shown $)$, which would be typically expected in a dairy cow. Oh et al. (1968) were the first to observe a decrease in VFA concentration in sheep and deer consuming EO from unpalatable species of plants. Since that time, most EO have been reported to have no effect on in vivo total or individual VFA in 
Table 3. Ammonia and VFA concentration in lactating Holstein dairy cows fed a 42:58 forage-to-concentrate ratio diet supplemented with essential oils

\begin{tabular}{|c|c|c|c|c|c|c|c|c|}
\hline \multirow[b]{2}{*}{ Item } & \multicolumn{4}{|c|}{ Treatment $^{1}$} & \multirow[b]{2}{*}{ SEM } & \multicolumn{3}{|c|}{ Effect $^{2}$} \\
\hline & $\mathrm{CON}$ & CE Lo & CE Hi & $\mathrm{CAP}$ & & $\mathrm{D}$ & $\mathrm{HPF}$ & $\mathrm{D} \times \mathrm{HPF}$ \\
\hline Total & 129.1 & 127.9 & 129.1 & 130.4 & 5.5 & 0.98 & $<0.01$ & 0.19 \\
\hline Acetate & 79.6 & 77.7 & 78.8 & 80.1 & 3.1 & 0.86 & $<0.01$ & 0.23 \\
\hline Propionate & 29.7 & 30.5 & 30.2 & 29.3 & 2.4 & 0.92 & $<0.01$ & 0.27 \\
\hline Isovalerate & 0.9 & 0.8 & 1.0 & 0.9 & 0.1 & 0.69 & 0.61 & 0.68 \\
\hline Valerate & 2.3 & 2.2 & 2.3 & 2.3 & 0.2 & 0.96 & $<0.01$ & 0.63 \\
\hline $\mathrm{A}: \mathrm{P}^{3}$ & 2.8 & 2.6 & 2.7 & 2.8 & 0.2 & 0.37 & 0.11 & 0.45 \\
\hline \multicolumn{9}{|l|}{ VFA, molar \% } \\
\hline Acetate & 61.7 & 60.8 & 61.2 & 61.6 & 1.1 & 0.67 & 0.39 & 0.66 \\
\hline Propionate & 22.8 & 23.8 & 23.2 & 22.2 & 1.1 & 0.33 & 0.08 & 0.38 \\
\hline Butyrate & 12.0 & 12.1 & 12.1 & 12.6 & 0.5 & 0.64 & 0.45 & 0.14 \\
\hline
\end{tabular}

${ }^{1} \mathrm{CON}=$ control (no oil); CE Lo $=0.5 \mathrm{~g} / \mathrm{d}$ of XT $6965(85 \mathrm{mg}$ of cinnamaldehyde and $140 \mathrm{mg}$ of eugenol; Pancosma S.A., Bellegarde-surValserine, France); CE Hi $=10 \mathrm{~g} / \mathrm{d}$ of XT 6965 (1,700 mg of cinnamaldehyde and 2,800 $\mathrm{mg}$ of eugenol); CAP = $0.25 \mathrm{~g} / \mathrm{d}$ of XT 6933 (capsicum). ${ }^{2} \mathrm{D}=$ diet; $\mathrm{HPF}=$ hours postfeeding; $\mathrm{D} \times \mathrm{HPF}=$ diet by hours postfeeding interaction.

${ }^{3}$ Acetate-to-propionate ratio.

sheep (Newbold et al., 2004), beef cattle (Cardozo et al., 2006), or dairy cattle (Benchaar et al., 2006, 2007, 2008). Research in beef cattle fed a 10:90 forage:concentrate ratio diet (Fandiño et al., 2008) reported that CAP $(0.5$ $\mathrm{g} / \mathrm{d} ; \sim 71.8 \mathrm{mg}$ of $\mathrm{CAP} / \mathrm{kg}$ of DM consumed) decreased acetate concentration and acetate-to-propionate ratio, and increased butyrate concentration. Still, the diet was very different from that used in the current study, and again, the dietary concentration of $\mathrm{EO}$ in DM used in the current study ( $11.0 \mathrm{mg}$ of CAP $/ \mathrm{kg}$ of DM consumed) was much lower, due to the higher DMI of dairy cows compared with that of beef heifers. Nonetheless, the results observed in the current study suggest that, even at a very high dosage (CE Hi), EO did not affect rumen fermentation to a great extent in lactating dairy cows.

\section{Rumen $\mathrm{pH}$}

To our knowledge, this is the first study to observe continuous rumen $\mathrm{pH}$ with EO supplementation. Mean rumen $\mathrm{pH}$ as well as number of bouts, total time, mean bout length, total area, and mean bout area $<\mathrm{pH} 5.8$ and 5.6 did not differ among treatments (Table 4), which was expected, as no change in VFA concentration occurred. In other research, rumen $\mathrm{pH}$ was not affected by the addition of CAP up to $2.5 \mathrm{~g} / \mathrm{d}$, although total VFA concentrations were increased (Fandiño et al., 2008; Rodriguez-Prado et al., 2008). However, even with $\mathrm{CE} \mathrm{Hi}$, VFA and $\mathrm{pH}$ were unaffected in the cur- rent study, reinforcing the little effect of these EO on ruminal fermentation. Again, this is most likely due to the major difference in diets between beef cattle studies, and the current dairy cattle study.

It is important to note, that although rumen $\mathrm{pH}$ characteristics were unaffected by $\mathrm{EO}$, the mean rumen $\mathrm{pH}$ of the cows in this study was low (5.6 to 5.8) compared with other EO studies in dairy cattle (6.3 to 6.7; Benchaar et al., 2006, 2007, 2008). This may be attributable to the observation that cows on all treatments consumed fewer meals/day than usually observed in lactating dairy cattle. Due to decreased frequency of meals, cows may have consumed more DM within each meal, which can cause sharper decreases in rumen $\mathrm{pH}$ that do not recover quickly. Ideally, cows should consume smaller, shorter meals to control sharp drops in rumen $\mathrm{pH}$ (Owens et al., 1998). In addition, evidence of sorting by all animals was found $(36.3 \% \mathrm{NDF}$ in orts compared with $28.6 \%$ NDF in TMR), possibly causing a deficiency in effective fiber consumption, although particle size of the orts was not measured. Rations that lack the proper amount of effective fiber cause decreased chewing, salivation, and consequently, decreased rumen $\mathrm{pH}$ (Yang and Beauchemin, 2007). Decreased rumen $\mathrm{pH}$ is linked to decreased nutrient digestibility (Kolver and de Veth, 2002). Indeed, the current study reported decreased $\mathrm{OM}$ and fiber, in situ digestibility of soybean hulls, and low total tract digestibilities. Moreover, although cows spent a similar amount of total time ruminating during the day (336 to $402 \mathrm{~min} / \mathrm{d}$ ) as observed 
Table 4. Rumen $\mathrm{pH}$ of lactating Holstein dairy cows fed a 42:58 forage-to-concentrate ratio diet supplemented with essential oils

\begin{tabular}{|c|c|c|c|c|c|c|}
\hline Item & \multicolumn{4}{|c|}{ Treatment $^{1}$} & SEM & $P$-value \\
\hline $\begin{array}{l}\text { Mean pH } \\
\mathrm{pH}<5.8\end{array}$ & 5.64 & 5.71 & 5.80 & 5.73 & 0.12 & 0.46 \\
\hline Bouts, n & 17.6 & 19.7 & 19.1 & 15.9 & 3.3 & 0.66 \\
\hline Total time, $\mathrm{h}$ & 14.6 & 15.3 & 12.0 & 16.0 & 2.3 & 0.40 \\
\hline Mean bout length, min & 69.8 & 55.2 & 46.6 & 53.7 & 17.7 & 0.51 \\
\hline Bouts, n & 20.8 & 22.1 & 18.5 & 19.1 & 2.8 & 0.72 \\
\hline Total time, $\mathrm{h}$ & 12.0 & 9.0 & 5.8 & 10.2 & 2.0 & 0.34 \\
\hline Mean bout length, min & 31.4 & 19.7 & 24.7 & 31.9 & 7.6 & 0.31 \\
\hline Total area, $\mathrm{pH} \cdot \mathrm{h} / \mathrm{d}$ & 2.8 & 2.9 & 1.9 & 2.9 & 1.0 & 0.79 \\
\hline Mean bout area, $\mathrm{pH} \cdot \mathrm{min} / \mathrm{d}$ & 9.4 & 5.0 & 9.6 & 8.8 & 4.2 & 0.65 \\
\hline
\end{tabular}

${ }^{1} \mathrm{CON}=$ control (no oil); CE Lo $=0.5 \mathrm{~g} / \mathrm{d}$ of XT 6965 (85 mg of cinnamaldehyde and $140 \mathrm{mg}$ of eugenol; Pancosma S.A., Bellegarde-surValserine, France); CE Hi $=10 \mathrm{~g} / \mathrm{d}$ of XT 6965 (1,700 mg of cinnamaldehyde and 2,800 mg of eugenol); CAP = $0.25 \mathrm{~g} / \mathrm{d}$ of XT 6933 (capsicum).

in other behavior studies (346 to $522 \mathrm{~min} / \mathrm{d}$; Krause and Combs, 2003; Yang and Beauchemin, 2007), they had fewer rumination events (10 to 10.5 events/d) that lasted longer (35.7 to 39.3 min) compared with those in other studies (13 to 17 events/d; 22.7 to $27.9 \mathrm{~min}$; Krause and Combs, 2003), suggesting that rumination activities may not have been spread out evenly, possibly causing lower mean $\mathrm{pH}$ over the course of the day due to uneven salivation and rumen buffering.

\section{Nutrient Digestibilities and In Situ Disappearance}

Total tract digestibility of DM, OM, NDF, ADF, CP, and starch did not differ among treatments (Table 5), demonstrating that these EO, even at high dosages, do not affect overall digestibility of feed. Very little literature exists discussing the effects of $\mathrm{EO}$ on total tract digestibility in dairy cattle. Moreover, most prior literature used blends that contained some different EO than the ones used in the current study. Still, no effects of a mixture of EO containing thymol, EUG, vanillin, and limonene fed at $2.0 \mathrm{~g} / \mathrm{d}$ (Benchaar et al., 2006) or a mixture of EO containing thymol, EUG, vanillin, guaicacol, and limonene fed at $0.75 \mathrm{~g} / \mathrm{d}$ (Benchaar et al., 2007) were reported on DM, NDF, CP, or starch digestibility. Unlike the current study, Benchaar et al. (2006) observed an increase in total tract ADF digestibility when feeding $2.0 \mathrm{~g} / \mathrm{d}$ of a mixture of EO. Although EUG was present in both blends, the discrepancy in ADF digestibility between studies may be due to the difference in blend of oils or dosages used. In addition, Benchaar et al. (2006) fed a diet with $24.4 \%$ ADF (28.0\% higher than in the current study), which may have increased the availability of fiber for digestion, thus increasing overall total tract digestibility of $\mathrm{ADF}$ in comparison with that in the current study.

Although total tract digestibility of nutrients was unaffected by EO, it is to be noted that digestibility of all nutrients in this study were low compared with similar studies. Several studies by Benchaar et al. (2006, 2007, 2008 ) reported total tract DM, OM, and CP digestibilities of $>60.0 \%$ and $\mathrm{NDF}$ and ADF digestibilities

Table 5. Total tract digestibility of lactating Holstein dairy cows fed a 42:58 forage-to-concentrate ratio diet supplemented with essential oils

\begin{tabular}{lcccccc}
\hline \multirow{2}{*}{$\begin{array}{l}\text { Total tract } \\
\text { digestibility, } \%\end{array}$} & \multicolumn{9}{c}{ Treatment $^{1}$} & & \\
\cline { 2 - 5 } & CON & CE Lo & CE Hi & CAP & SEM & $P$-value \\
\hline DM & 51.4 & 51.9 & 53.8 & 53.0 & 3.4 & 0.75 \\
OM & 52.6 & 53.7 & 55.5 & 55.3 & 3.4 & 0.68 \\
NDF & 29.6 & 27.4 & 35.4 & 30.3 & 6.0 & 0.73 \\
ADF & 30.4 & 28.2 & 32.5 & 31.6 & 4.5 & 0.77 \\
CP & 51.3 & 46.4 & 52.3 & 50.9 & 5.1 & 0.54 \\
Starch & 87.6 & 89.2 & 88.3 & 90.8 & 3.2 & 0.76 \\
\hline
\end{tabular}

${ }^{1} \mathrm{CON}=$ control (no oil); $\mathrm{CE} \mathrm{Lo}=0.5 \mathrm{~g} / \mathrm{d}$ of XT 6965 (85 mg of cinnamaldehyde and $140 \mathrm{mg}$ of eugenol; Pancosma S.A., Bellegarde-sur-Valserine, France); CE Hi = $10 \mathrm{~g} / \mathrm{d}$ of XT 6965 (1,700 mg of cinnamaldehyde and $2,800 \mathrm{mg}$ of eugenol); $\mathrm{CAP}=0.25 \mathrm{~g} / \mathrm{d}$ XT 6933 (capsicum). 
Table 6. Twenty-four-hour in situ nutrient disappearance of soybean hulls in lactating Holstein dairy cows fed a 42:58 forage-to-concentrate ratio diet supplemented with essential oils

\begin{tabular}{|c|c|c|c|c|c|c|}
\hline \multirow{2}{*}{$\begin{array}{l}\text { 24-h in situ } \\
\text { nutrient } \\
\text { disappearance, \% }\end{array}$} & \multicolumn{4}{|c|}{ Treatment $^{1}$} & \multirow[b]{2}{*}{ SEM } & \multirow[b]{2}{*}{$P$-value } \\
\hline & $\mathrm{CON}$ & CE Lo & CE Hi & CAP & & \\
\hline DM & 59.7 & 60.8 & 60.3 & 57.9 & 2.4 & 0.56 \\
\hline OM & $60.3^{\mathrm{a}}$ & $58.6^{\mathrm{ab}}$ & $57.6^{\mathrm{b}}$ & $59.1^{\mathrm{ab}}$ & 2.3 & 0.08 \\
\hline NDF & $41.5^{\mathrm{a}}$ & $38.2^{\mathrm{ab}}$ & $37.6^{\mathrm{b}}$ & $38.0^{\mathrm{ab}}$ & 3.0 & 0.05 \\
\hline $\mathrm{ADF}$ & $44.5^{\mathrm{a}}$ & $41.6^{\mathrm{ab}}$ & $38.8^{\mathrm{b}}$ & $40.0^{\mathrm{ab}}$ & 2.8 & 0.04 \\
\hline
\end{tabular}

$>45.0 \%$, whereas the current study resulted in DM and $\mathrm{OM}$ digestibilities of $<56.0 \%$, digestibility of $\mathrm{CP}$ $<53.0 \%$, and digestibility of NDF and $\mathrm{ADF}<35.0 \%$. Although only $4 \%$ lower (calculated geometric mean length, $\mathrm{X}_{\mathrm{gm}}=4.8$ ) than the recommended particle size $\left(\mathrm{X}_{\mathrm{gm}}>5.0\right)$, the depressed total tract digestibility observed in the current study may be linked to the particle size of the TMR. Small particle size can cause faster passage of feed particles, and consequently, decreased total tract digestibility of nutrients. Indeed, lower than average digestibilities were observed for all treatments in this study.

Twenty-four hours in situ DM disappearance of soybean hulls was not affected by EO. However, compared with CON, CE Hi depressed NDF (41.5 vs. $37.6 \% ; P=$ 0.05 ) and $\mathrm{ADF}$ (44.5 vs. $38.8 \% ; P=0.04$ ) disappearance as well as causing a trend toward decreased OM disappearance ( 60.3 vs. $57.6 \%$; $P=0.08$; Table 6 ), suggesting that rumen fermentation was altered by such a high dosage of EO. Benchaar et al. (2008) supplemented CIN at a recommended dosage of $1 \mathrm{~g} / \mathrm{cow}$ per day and reported no effect on in situ digestibility of soybean meal in lactating dairy cattle. However, in sheep fed a blend of EO $(0.11 \mathrm{~g} / \mathrm{d}$; thymol, guaicacol, and limonene), Newbold et al. (2004) observed depressed in situ DM disappearance of soybean meal. Like beef cattle, sheep have a smaller DMI/kg of BW compared with dairy cattle, and consequently, the concentration of EO in the study by Newbold et al. (2004) was very high $(110 \mathrm{mg} / \mathrm{kg}$ of DM consumed) compared with beef studies where diets contained $<75 \mathrm{mg}$ of $\mathrm{EO} / \mathrm{kg}$ of DM consumed. Similar results were found for CE Hi in the current study where the concentration of EO was exceptionally high $(\sim 425.0 \mathrm{mg} / \mathrm{kg}$ of $\mathrm{DM}$ consumed $)$, thus causing altered nutrient disappearance.

This is the first study to feed such a high dosage of EO to lactating dairy cattle. The negative effects on in situ digestibility observed in the current study with $\mathrm{CE} \mathrm{Hi}$ are in concordance with a previous in vitro study by Tager and Krause (2010). In this continuous culture study, CIN tended to decrease OM digestibility and both CIN and EUG strongly numerically decreased NDF and ADF digestibility in continuous culture at a dosage of $500 \mathrm{mg} / \mathrm{L}$. Therefore, the results observed for $\mathrm{CE} \mathrm{Hi}$, which would be equal to approximately 100 $\mathrm{mg} / \mathrm{L}$ in continuous culture, only validated the results observed for CIN and EUG previously in vitro. Again, it is also important to note that the TMR had smaller particle size than would be considered optimal for lactating dairy cattle, thus leading to decreased rumen digestibility of nutrients. However, because there was no change in total tract digestibility of $\mathrm{OM}$ or fiber with $\mathrm{CE} \mathrm{Hi}$, it seems that the in situ depression of these nutrients may have been compensated for post ruminally. Moreover, the fiber content of soybean hulls $(67.0 \% \mathrm{NDF})$ is much higher than that of the TMR (28.6\% NDF), which may also account for the difference in in situ OM, ADF, and NDF disappearance and total tract digestibilities.

\section{Milk Yield and Composition}

Milk yield and composition were not affected by the addition of EO (Table 7), not surprisingly, as no change in DMI, VFA, or total tract nutrient digestibility was observed. This finding is in agreement with other studies in dairy cattle (Benchaar et al., 2006, 2007, 2008), where milk yield and composition were unchanged by EO. Little published evidence exists showing increased production or change in milk composition with EO supplementation.

\section{CONCLUSIONS}

At the manufacturer's recommended dosage, CE Lo had no effect on rumen fermentation, milk production, or feeding behavior, suggesting that the recommended dosage of this blend for lactating dairy cattle brings no added benefit. The results observed here with CE Hi were consistent with those observed with high in 
Table 7. Milk yield and composition of lactating Holstein dairy cows fed a 42:58 forage-to-concentrate ratio diet supplemented with essential oils

\begin{tabular}{lcccccc}
\hline & \multicolumn{9}{c}{ Treatment $^{1}$} & & \\
\cline { 2 - 5 } Item & CON & CE Lo & CE Hi & CAP & SEM & $P$-value \\
\hline Milk yield, kg/d & 33.0 & 32.8 & 31.6 & 31.1 & 1.2 & 0.35 \\
Milk composition & 3.5 & 3.5 & 3.4 & 3.6 & 0.2 & 0.63 \\
Fat, \% & 1.2 & 1.2 & 1.1 & 1.1 & 0.1 & 0.61 \\
Fat, kg/d & 4.8 & 4.8 & 4.8 & 4.8 & 0.1 & 0.86 \\
Lactose, \% & 1.6 & 1.6 & 1.5 & 1.5 & 0.1 & 0.28 \\
Lactose, $\mathrm{kg} / \mathrm{d}$ & 2.8 & 2.8 & 3.5 & 2.7 & 0.4 & 0.41 \\
Protein, \% & 0.9 & 0.9 & 1.0 & 0.9 & 0.1 & 0.61 \\
Protein, $\mathrm{kg} / \mathrm{d}$ & & &
\end{tabular}

${ }^{1} \mathrm{CON}=$ control (no oil); CE Lo $=0.5 \mathrm{~g} / \mathrm{d}$ of XT 6965 (85 mg of cinnamaldehyde and $140 \mathrm{mg}$ of eugenol; Pancosma S.A., Bellegarde-sur-Valserine, France); CE Hi = $10 \mathrm{~g} / \mathrm{d}$ of XT 6965 (1,700 mg of cinnamaldehyde and 2,800 $\mathrm{mg}$ of eugenol); CAP $=0.25 \mathrm{~g} / \mathrm{d}$ of XT 6933 (capsicum).

vitro dosages previously. At such a high dosage, $\mathrm{CE} \mathrm{Hi}$ negatively affected in situ nutrient fermentation and altered eating behavior, indicating that a dosage of 10 $\mathrm{g} / \mathrm{d}$ is not beneficial to lactating dairy cows. On the other hand, CAP shortened the length of the first meal without changing rumen fermentation or production, making it a possible feed additive for altering feeding behavior and rumen acidosis. However, more extensive feeding behavior research is required to validate this. At these dosages, the oils tested in the current study are not an appropriate rumen modifier for dairy cattle.

\section{ACKNOWLEDGMENTS}

The authors thank Will McClung and the staff of the West Virginia University Research Farm (Morgantown, West Virginia) for their support in planning and executing this study. Provision of EO from Pancosma, S.A. (Bellegarde-sur-Valserine, France) is much appreciated. This work is published with the approval of the Director of West Virginia Agriculture and Forestry Experiment Station as scientific paper 3091. This project was supported by Hatch project 474 .

\section{REFERENCES}

AOAC. 1995. Official Methods of Analysis. Vol I. 16th ed. Association of Official Analytical Chemists, Arlington, VA.

ASAE. 2001. Method of determining and expressing particle size of chopped forage materials by sieving. S424 in Standards. Am. Soc. Agric. Eng., St. Joseph, MI.

Benchaar, C., T. A. McAllister, and P. Y. Chouinard. 2008. Digestion, ruminal fermentation, ciliate protozoal populations, and milk production from dairy cows fed cinnamaldehyde, quebracho condensed tannin, or Yucca schidigera saponin extracts. J. Dairy Sci. 91:4765-4777.

Benchaar, C., H. V. Petit, R. Berthiaume, D. R. Ouellet, J. Chiquette, and P. Y. Chouinard. 2007. Effects of essential oils on digestion, ruminal fermentation, rumen microbial populations, milk production, and milk composition in dairy cows fed alfalfa silage or corn silage. J. Dairy Sci. 90:886-897.
Benchaar, C., H. V. Petit, R. Berthiaume, T. D. Whyte, and P. Y. Chouinard. 2006. Effects of addition of essential oils and monensin premix on digestion, ruminal fermentation, milk production, and milk composition in dairy cows. J. Dairy Sci. 89:4352-4364.

Busquet, M., S. Calsamiglia, A. Ferret, and C. Kamel. 2006. Plant extracts affect in vitro rumen microbial fermentation. J. Dairy Sci. 89:761-771.

Calsamiglia, S., M. Busquet, P. W. Cardozo, L. Castillejos, and A. Ferret. 2007. Invited review: Essential oils as modifiers of rumen microbial fermentation. J. Dairy Sci. 90:2580-2595.

Cardozo, P. W., S. Calsamiglia, A. Ferret, and C. Kamel. 2006. Effects of alfalfa extract, anise, capsicum and a mixture of cinnamaldehyde and eugenol on ruminal fermentation and protein degradation in beef heifers fed a high-concentrate diet. J. Anim. Sci. 84:2801-2808.

Castillejos, L., S. Calsamiglia, A. Ferret, and R. Losa. 2005. Effects of a specific blend of essential oil compounds and the type of diet on rumen microbial fermentation and nutrient flow from a continuous culture system. Anim. Feed Sci. Technol. 119:29-41.

Deriaz, R. E. 1961. Routine analysis of carbohydrates and lignin in herbage. J. Sci. Food Agric. 12:152-160.

DeVries, T. J., K. A. Beauchemin, and M. A. G. von Keyserlingk. 2007. Dietary forage concentration affects the feed sorting behavior of lactating dairy cows. J. Dairy Sci. 90:5572-5579.

Eastridge, M. L. 2006. Major advances in applied dairy cattle nutrition. J. Dairy Sci. 89:1311-1323.

Fraser, G. R., A. V. Chaves, Y. Wang, T. A. McAllister, K. A. Beauchemin, and C. Benchaar. 2007. Assessment of the effects of cinnamon leaf oil on rumen microbial fermentation using two continuous culture systems. J. Dairy Sci. 90:2315-2328.

French, N., and J. J. Kennelly. 1990. Effects of feeding frequency on ruminal parameters, plasma insulin, milk yield, and milk composition in Holstein cows. J. Dairy Sci. 73:1857-1863.

Hartnell, G. F., and L. D. Satter. 1979. Determination of rumen fill, retention time and ruminal turnover rates of ingesta at different stages of lactation in dairy cows. J. Anim. Sci. 48:381-392.

Kolver, E. S., and M. J. de Veth. 2002. Prediction of ruminal pH from pasture-based diets. J. Dairy Sci. 85:1255-1266.

Kononoff, P. J., A. J. Heinrichs, and D. R. Buckmaster. 2003. Modification of the Penn State Forage and Total Mixed Ration Particle Separator and effects of moisture content on its measurements. J. Dairy Sci. 86:1858-1863.

Krause, K. M., and D. K. Combs. 2003. Effects of forage particle size, forage source, and grain fermentability on performance and ruminal pH in midlactation cows. J. Dairy Sci. 86:1382-1397.

Newbold, C. J., F. M. McIntosh, P. Williams, R. Losa, and R. J. Wallace. 2004. Effects of a specific blend of essential oil compounds on rumen fermentation. Anim. Feed Sci. Technol. 114:105-112.

NRC. 2001. Nutrient Requirements of Dairy Cattle. 7th rev. ed. Natl. Acad. Sci., Washington, DC. 
Oh, H. K., M. B. Jones, and W. M. Longhurst. 1968. Comparison of rumen microbial fermentation inhibition resulting from various essential oils isolated from relatively unpalatable plant species. Appl. Microbiol. 16:39-44.

Owens, F. N., D. S. Secrist, W. J. Hill, and D. R. Gill. 1998. Acidosis in cattle: A review. J. Anim. Sci. 76:275-286.

Penner, G. B., K. A. Beauchemin, and T. Mutsvangwa. 2006. An evaluation of the accuracy and precision of a stand-alone submersible continuous ruminal pH measurement system. J. Dairy Sci. $89: 2132-2140$

Rodriguez-Prado, M.,, S. Calsamiglia, A. Ferret, J. Zwieten, L. Gonzalez, and D. Bravo. 2008. Effects of cinnamaldehyde-eugenol and capsicum on rumen fermentation and feeding behavior in beef heifers fed a high-concentrate diet. J. Anim. Sci. 86(Suppl. 2):588 (Abstr.)

SAS Institute. 2001. SAS User's Guide: Statistics. Version 9.1. SAS Inst. Inc., Cary, NC.
Smith, D. 1969. Removing and analyzing non-structural carbohydrates from plant tissue. Page 1 in Wisconsin Agric. Exp. Sta. Res. Rep. 41. Wisconsin Agric. Exp. Sta., Madison, WI.

Tager, L. R., and K. M. Krause. 2010. Effects of cinnamaldehyde, eugenol, and capsicum on fermentation of a corn-based dairy ration in continuous culture. Can. J. Anim. Sci. 90:413-420.

Wallace, R. J. 2005. Symposium: Plants as animal foods: A case of catch 22?: Antimicrobial properties of plant secondary metabolites. Proc. Nutr. Soc. 63:621-629.

Wangsness, P. J., L. E. Chase, A. D. Peterson, T. G. Hartsock, D. J. Kellmel, and B. R. Baumgardt. 1976. System for monitoring feeding behavior of sheep. J. Anim. Sci. 42:1544-1549.

Yang, W. Z., and K. A. Beauchemin. 2007. Altering physically effective fiber intake through forage proportion and particle length: Chewing and ruminal pH. J. Dairy Sci. 90:2826-2838. 